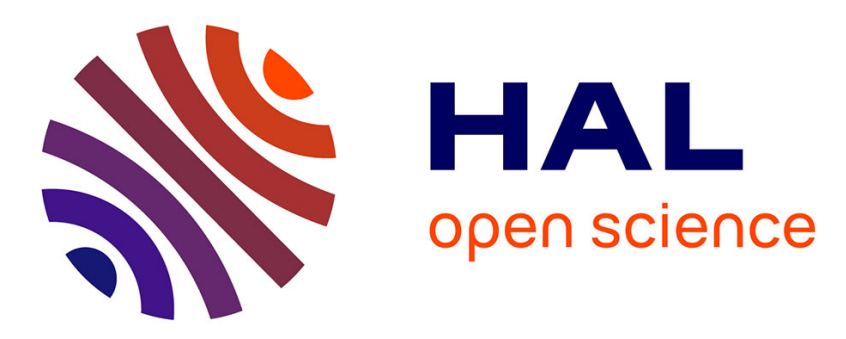

\title{
Seismic evidence of gas hydrates, multiple BSRs and fluid flow offshore Tumbes Basin, Peru
}

Constance Auguy, Gérôme Calvès, Ysabel Calderon, Stéphane Brusset

\section{To cite this version:}

Constance Auguy, Gérôme Calvès, Ysabel Calderon, Stéphane Brusset. Seismic evidence of gas hydrates, multiple BSRs and fluid flow offshore Tumbes Basin, Peru. Marine Geophysical Research, 2017, 10, pp.339-339. 10.1007/s11001-017-9319-2 . hal-01539107

\section{HAL Id: hal-01539107 https://hal.science/hal-01539107}

Submitted on 14 Jun 2017

HAL is a multi-disciplinary open access archive for the deposit and dissemination of scientific research documents, whether they are published or not. The documents may come from teaching and research institutions in France or abroad, or from public or private research centers.
L'archive ouverte pluridisciplinaire HAL, est destinée au dépôt et à la diffusion de documents scientifiques de niveau recherche, publiés ou non, émanant des établissements d'enseignement et de recherche français ou étrangers, des laboratoires publics ou privés. 
1 Seismic evidence of gas hydrates, multiple BSRs and fluid

$4 \quad{ }^{1}$ Université Toulouse 3, GET-OMP, 14 Avenue Edouard Belin, 31400, Toulouse, France

5 (*corresponding author, gerome.calves@get.omp.eu, phone: +33561332598, fax: +33561332560)

$6 \quad{ }^{2}$ PeruPetro, Lima, Peru.

8 ABSTRACT (247 words)

9 Identification of a previously undocumented hydrate system in the Tumbes Basin, localized off the north

10 Peruvian margin at latitude of $3^{\circ} 20^{\prime}-4^{\circ} 10^{\prime} \mathrm{S}$, allows us to better understand gas hydrates of convergent

11 margins, and complement the 36 hydrate sites already identified around the Pacific Ocean. Using a 12 combined 2D-3D seismic dataset, we present a detailed analysis of seismic amplitude anomalies related 13 to the presence of gas hydrates and/or free gas in sediments. Our observations identify the occurrence of 14 a widespread Bottom Simulating Reflector (BSR), under which we observed, at several sites, the 15 succession of one or two BSR-type reflections of variable amplitude, and vertical acoustic discontinuities 16 associated with fluid flow and gas chimneys. We conclude that the uppermost BSR marks the current 17 base of the hydrate stability field, for a gas composition comprised between $96 \%$ methane and $4 \%$ of 18 ethane, propane and pure methane. Three hypotheses are developed to explain the nature of the multiple 19 BSRs. They may refer to the base of hydrates of different gas composition, a remnant of an older BSR in 20 the process of dispersion/dissociation or a diagenetically induced permeability barrier formed when the 21 active BSR existed stably at that level for an extended period. The multiple BSRs have been interpreted 22 as three events of steady state in the pressure and temperature conditions. They might be produced by 23 climatic episodes since the last glaciation associated with tectonic activity, essentially tectonic subsidence, 24 one of the main parameters that control the evolution of the Tumbes Basin.

27 Gas hydrates, Bottom Simulating Reflector, multiple BSRs, seismic chimneys, Tumbes, Peru. 
Multiple BSRs and fluid flow offshore Tumbes Basin, Peru. R1

Introduction

29 Natural gas hydrates have gained international attention over the last few decades for energy, safety 30 and environmental reasons (Kvenvolden, 1993; Milkov, 2004; Sultan et al., 2004). Because they are 31 thermodynamic products, they can be extremely useful to indirectly estimate heat flow of continental 32 margins (Yamamo et al., 1982), and can provide valuable information on environmental and/or tectonic 33 evolution of a sedimentary basin.

34 Gas hydrates are formed by a lattice of water molecules held together by hydrogen bonding, and 35 stabilized by the inclusion of a guest molecule, typically low molecular weight gas (Ballard and Sloan, 36 2002). Natural gas molecules trapped in hydrate consist mainly of methane, but other higher and non37 hydrocarbons, such as nitrogen, hydrogen sulfide or carbon dioxide, can also form hydrates. To form, gas 38 hydrates need high pressure, low temperature, and the right amount of water and gas (Kvenvolden, 1993), 39 conditions commonly found in oceanic sediments along continental margins, at water depths greater than $40400 \mathrm{~m}$. The field of hydrate stability, called the Gas Hydrate Stability Zone (GHSZ), comprises the first few 41 hundred meters of the sedimentary section. It is largely controlled by pressure and temperature 42 conditions, and is limited in depth due to increasing temperature from the local geothermal gradient.

43 In seismic reflection section, a common indicator of submarine gas hydrates is a Bottom-Simulating 44 Reflector (BSR) (Shipley et al., 1979), although its absence does not necessarily mean absence of 45 hydrates in sediments (Vanneste et al., 2001). A hydrate-related BSR mimics the seafloor topography and 46 crosscuts the sedimentary strata as it follows the GHSZ. It is characterized by a strong negative 47 impedance contrast due to high-velocity sediments containing hydrates above the base of the hydrate 48 stability field and lower-velocity sediments containing free gas beneath it (Field and Kvenvolden, 1985). If 49 the gas composition is known, the in situ temperature at the BSR can be estimated from the depth of this 50 reflector.

51 When a hydrate system is not in thermodynamic equilibrium, the position of the BSR is expected to 52 change. Multiple BSR-type reflections, subparallel to the seafloor but at different sub-bottom depths, have 53 been observed in both active and passive margins, as the Storegga Slide area on the Norwegian margin 54 (Posewang and Mienert, 1999; Andreassen et al.,2000)), the upper slope of the SE Nankai margin (Foucher 55 et al., 2002), in the Yaquina and Trujillo Basins off Peru (Hübscher and Kukowski, 2003; Herbozo et al., 
Multiple BSRs and fluid flow offshore Tumbes Basin, Peru. R1

56 2013), at Hydrate Ridge on Cascadia margin (Bangs et al., 2005), in the Danube deep-sea fan on the NW

57 Black Sea margin (Popescu et al., 2006), or in the Mohican Channel area on the central Scotian Slope

58 (Mosher, 2008). The origin of these multiple reflectors is not well understood, and several interpretations

59 have been suggested, i.e. residual BSR in the process of dispersing, layers of hydrates of different gas 60 composition, or diagenetic reaction.

61 Along South American continental margins, numerous accumulations of gas hydrates are known and have been described (Kvenvolden and Kastner, 1990; Brown et al., 1996; Pecher et al., 2001; Hubscher

63 and Kukowski, 2003; Rodrigo et al., 2009). Off Peru, during Ocean Drilling Program (ODP) Leg 112, gas

64 hydrates were identified in water depth greater than $3000 \mathrm{~m}$, within core drillings, and on seismic profiles 65 crossing the Yaquina and Lima forearc Basins (sites 682, 685, and 688) (von Huene et al., 1987) (Figure 66 1A). The occurrence of BSRs in these basins was interpreted to reflect a history of vertical tectonism, 67 sedimentation, and carbon concentrations in sediments (von Huene and Pecher, 1999). Off margin north 68 of Peru, no data were available until recent 2D-3D seismic reflection data acquisition in the Tumbes Basin, 69 which allowed the identification of a new hydrate province (Figure 1B).

70 The purpose of this study is to (1) document the hydrates in the Tumbes Basin (2) describe associated

71 fluid seeps (3) estimate the thermal regime and (4) discuss the influence of climatic changes and tectonic 72 factors related to the evolution of the margin that help generate multiple BSRs.

\section{2. Geological framework}

74 The Tumbes Basin is a particular type of forearc basin which evolves in response to subduction 75 dynamics of the Nazca plate beneath the South America plate. The study area, located offshore northern 76 Peru between $3^{\circ} 20$ and $4^{\circ} 10 \mathrm{~S}$, consists of a several-kilometer-thick accumulation of Oligocene to 77 Quaternary sediment characterized by normal faulting (Figure 1C). It is delineated by three major N-S78 trending normal and low-angle gravity-driven fault systems. These gravitational tectonic features have 79 generated rollover anticlines and rotated fault blocks during Pliocene-Pleistocene times. To the west, an 80 east-dipping normal fault bounds the eastern flank of Banco Peru, a flat shallow-depth seafloor high 81 located 30-50 km seaward from the coast, which bounds the extension of the basin to the west. The 82 southern limit of the basin occurs near $4^{\circ} \mathrm{S}$ as the triple junction between these two major fault systems 83 and a south-dipping listric normal fault branched onto the Talara detachment, which extends to the Peru- 
Multiple BSRs and fluid flow offshore Tumbes Basin, Peru. R1

84 Chile trench axis at $\sim 5^{\circ} S$ (Bourgois et al., 2007). The presence of multiple reservoirs, giant oil 85 accumulation in the onshore fields of the Talara Basin and different hydrocarbon occurrences in the 86 eastern shallow-depth Tumbes Basin (Deckelman et al., 2005), makes the study area a promising region 87 for hydrocarbon exploration.

\section{3. Data and methods}

89 The seismic reflection dataset was acquired over exploration block Z-38, in water depths ranging from $90110 \mathrm{~m}$ to $2765 \mathrm{~m}$, offshore Tumbes Basin (Figure 1B). The 2D mutli-channel seismic data acquired in 912009 has a total survey length of about $2393 \mathrm{~km}$. The dataset has a sampling rate of $2 \mathrm{~ms}$. The frequency 92 content ranges between $10-70 \mathrm{~Hz}$ and the 2D grid spacing ranges from 1 to $6 \mathrm{~km}$. Dominant frequencies 93 around $45 \mathrm{~Hz}$ for the shallow subsurface provide a theoretical vertical resolution $(\mathrm{N} / 4)$ of $\sim 10 \mathrm{~m}(\mathrm{P}$-wave 94 velocity in sediments of $1800 \mathrm{~m} / \mathrm{s}$ ). The 3D seismic dataset, acquired in 2010, covers an area of 1500 $95 \mathrm{~km}^{2}$. It has a sampling rate of $4 \mathrm{~ms}$. The 3D grid is subdivided into inline and crossline directions, spaced 96 at $25 \mathrm{~m}$ and $12.5 \mathrm{~m}$ respectively. The frequency of the seismic signal in the shallow subsurface ranges 97 between 5 and $90 \mathrm{~Hz}$ with a dominant frequency around $45-55 \mathrm{~Hz}$. Assuming a velocity of $1800 \mathrm{~m} / \mathrm{s}$, the 98 theoretical vertical resolution $(\lambda / 4)$ is $\sim 9 \mathrm{~m}$.

99 The seismic data have been interpreted using standard seismic stratigraphic techniques (Mitchum et al., 100 1977), based on reflection terminations and seismic facies reflection characteristics. Geometric seismic 101 attributes, such as similarity, have been used to enhance recognition of coherent events and emphasize 102 discontinuities such as faults and stratigraphic surfaces. Using these techniques, a framework of four 103 interpreted seismic horizons (seafloor, $\mathrm{H} 1, \mathrm{H} 2$ and H3; Figure 2A) has been used in the Mancora Basin, a 104 sub-basin of the Tumbes Basin (red dashed box Figure 1B), in order to obtain accurate and detailed 105 information on amplitude anomalies, depositional elements, structural patterns, direct hydrocarbon 106 indicators (DHI), and sediment remobilization or fluid flow features (Calvès et al., 2008).

107 As hydrates are only stable in a very limited range of temperatures and pressures (Yamano et al., 1982; 108 Sloan, 1998), the occurrence of BSRs related to methane hydrates in the shallow subsurface allows us to 109 estimate the thermal regime. This estimation is based on the assumption that the BSR is related to the 110 base of the GHSZ. We have used information from seismic reflection surveys, seabed temperature from 111 World Ocean Database (http://www.nodc.noaa.gov/OC5/WOD09/pr_wod09.html-2009) and Sloan's 
Multiple BSRs and fluid flow offshore Tumbes Basin, Peru. R1

112 (1998) phase boundary diagram for pure methane and $3.5 \mathrm{wt} \%$ seawater. The workflow consists of the

113 following steps (e.g. Calvès et al., 2010): (1) picking of seabed and regional BSR horizons, (2) conversion

114 from two-way time (TWT) to depth, based on a P-wave velocity of $1475 \mathrm{~m} / \mathrm{s}$ in seawater and $1800 \mathrm{~m} / \mathrm{s}$ in

115 sediments, (3) conversion from BSR depth to temperature using a phase boundary diagram, (4)

116 determination of the thermal gradient computed by dividing the temperature difference between the

117 seabed and the BSR by the subbottom depth.

118 4. Results

119 4.1. Seismic evidence of multiple BSRs: characteristics and distribution

120 Analysis of seismic reflection profiles revealed the presence of numerous BSRs in water depths of 470 -

$1212410 \mathrm{~m}$. We identified an extensive BSR (Figure 1D and upper BSR, Figure 3) under which we observed,

122 at several sites, the succession of one or two BSR-type reflections at different depths (intermediate and

123 lower BSRs, Figure 3). All of them mimic the seafloor topography, cross-cutting stratigraphic horizons, and

124 display reversed polarity relative to the seafloor reflection. Below these multiple BSRs, enhanced 125 reflections are commonly observed (e.g. HAA: Calvès et al., 2008; Figure 3A). This association of BSRs

126 with reversed apparent polarity and the abrupt termination of enhanced reflections against them indicate

127 the occurrence of gas hydrates overlying free gas accumulations. Other anomalous amplitude reflections

128 are observed in the shallow subsurface, and identified as Direct Hydrocarbon Indicators (DHIs) (Figure

129 2B). DHIs are particularly present in the SW part of the 3D seismic block in the intra-slope Mancora Basin

130 (Figure 2A), where they occur as local increases or decreases in reflection amplitudes (called bright

131 spots/flat spots or dim outs respectively), phase reversals along particular sedimentary reflections and

132 BSRs, and columnar disturbances linked to fluid seeps, which are interpreted as seismic chimneys.

133 Among the multiple BSRs identified, the upper one (Figure 1D and upper BSR, Figure 3) is the longest 134 and can be followed over distances of up to $15 \mathrm{~km}$ without interruption. The isochore of the interval from 135 the seabed to the upper BSR (Figure 4A) shows a variation in thickness from 170 to $560 \mathrm{~m}$, and increases 136 with increasing water depth, i.e. with pressure; it is controlled by the gas hydrate stability conditions. As 137 observed in other hydrate provinces, the upper BSR undergoes important amplitude variations depending 138 on which structural features or geological elements it intersects (Ashi et al., 2002; Lin et al., 2008). 139 Contrary to observations done in the Yaquina Basin further south by Hübscher and Kukowski (2003), the 
Multiple BSRs and fluid flow offshore Tumbes Basin, Peru. R1

140 upper BSR is most easily recognized where it cross-cuts sedimentary strata. It displays strong amplitude

141 in anticline structures, or cross-cutting inclined stratal reflections on structural ridges, and is weaker in 142 synclinal structures, slope basins, or sub-marine canyons. In the intra-slope Mancora Basin, the upper 143 BSR cross-cuts parallel stratified sediments with a small angle (Figure 2A). Its reflection is superimposed 144 on the underlying sedimentary reflections, which makes it difficult to follow. On some seismic profiles, that 145 intersection can be seen and is characterized by local decreases in amplitude and polarity changes of the 146 strong sedimentary reflections intersected (dim out and phase reversal - Figures 2A and 2B).

147 Intermediate BSRs are observed at depths ranging from 36 to $72 \mathrm{~m}$ (40 to $80 \mathrm{~ms}$ TWT) below the upper 148 BSR. They appear as negative polarity reflections or an upper limit of enhanced reflections, mimicking the 149 seafloor topography (Figures $3 \mathrm{~A}$ and $3 \mathrm{~B}$ ). As with the upper BSR, they have a water-depth dependence 150 (Figure 4B), but are much more discontinuous. They occur locally as patches of high amplitude reflections 151 of 50 to $250 \mathrm{~m}$ (Figure 4C), or as reflection segments of 1000 to $2600 \mathrm{~m}$ (Figure 4D), and are generally 152 located in zones strongly affected by normal faults.

153 Lower BSRs are observed at depths ranging from 115 to $190 \mathrm{~m}$ (130 to $210 \mathrm{~ms}$ TWT) below the upper 154 BSR. They appear as discontinuous reflection segments of 200 to $2800 \mathrm{~m}$ long, display reversed polarity 155 and are, in most seismic profiles where they occur, the BSRs showing the strongest amplitude values. 156 They are present within different structural and sedimentological settings, from a buried structural high 157 with near-vertical stratal reflections (Figures $3 \mathrm{~A}$ and $4 \mathrm{C}$ ), to stratigraphic layers sub-parallel to the seabed 158 and affected by normal faults (Figure 3B).

159 A particular type of HAA, which have the same negative polarity as a hydrate-related BSR but are 160 affected by a fault system that shifts them downward, are observed in the Mancora Basin (Figures 2A and $1613 \mathrm{3}$ ). Approximately parallel to the seabed, they extend semi-continuously over the intra-slope basin, 162 cross-cutting the background inclined sedimentary reflections. Their depth below seafloor varies from 480 163 to $810 \mathrm{~m}$ (530 ms to $810 \mathrm{~ms}$ TWT) for water depths of $950-1030 \mathrm{~m}$ respectively. In seismic profiles 164 oriented NW-SE, they appear as flat spot of over $2000 \mathrm{~m}$ long (yellow triangle, Figure 2A), while in seismic 165 profiles oriented perpendicularly (SW-NE), they appear as high reflectivity segments shifted down 166 between sub-parallel normal faults (right profile, Figure $3 C$ ). The extension of these HAA is difficult to 
Multiple BSRs and fluid flow offshore Tumbes Basin, Peru. R1

167 visualize due to their location at the boundary between the 3D block and the 2D seismic data, but they

168 seem to fit with the lower BSR observed in the 2D seismic profile (NW-SE section- Figure 3C).

\section{4.2. Distribution of fluid seeps}

170 In the Mancora Basin, within $\sim 100 \mathrm{~km}^{2}$ imaged by the 3D seismic reflection (Figure 5), we have identified 171 a series of pockmarks/mounds that consist of patches of HAA on the seabed and 10-15 m deep/high on 172 seismic profiles. These features are the expressions of focused fluid flow activity on the seabed (Judd and 173 Hovland, 2009; Hustoft et al., 2009). Depending on their morphology, we defined two categories of 174 pockmarks: the circular or elliptic ones, typically measuring from 40 to $350 \mathrm{~m}$ in diameter, and the 175 elongated ones, which have one axis that is much longer than the other, up to $500 \mathrm{~m}$ (e.g. chimney $\alpha$ : 85 $176 \mathrm{~m}$ wide, and $515 \mathrm{~m}$ long, Figures 5 and 6 ). Underlying the pockmarks/mounds field lies a corresponding 177 series of vertical seismic chimneys, i.e. the acoustic imprint of fluid migration. Time-structure/similarity 178 attribute maps of three paleo-surfaces illustrates the subsurface expression of the fluid-escape chimneys 179 in plan form $(\mathrm{H} 1, \mathrm{H} 2, \mathrm{H} 3$, Figures $2 \mathrm{~A}$ and 6$)$. The maps show that chimneys are represented by circular 180 and elongated well-exposed anomalies, and reveal a preferred direction of the elongated chimneys, with 181 the longest axis perpendicular to the faulting. This preferred direction remains commonly constant with 182 depth (Figure 6). In seismic reflection sections, the chimneys appear as columnar zones of low coherence 183 and reduced reflectivity, where surrounding strata can be both truncated or flexed upward at their flanks. 184 Of 48 seismic chimneys identified, one fifth are buried chimneys ending at different stratigraphic levels, 185 generally with a patch of high amplitude reflections or intra-sedimentary doming, i.e. deflected upward 186 reflections stopped into the sediment column (e.g. chimneys $y$ and $\delta$, Figure 5). A typical chimney has a 187 root zone that in the seismic data appears to originate below the strong stratigraphic clustering that occurs 188 throughout the intra-slope basin, between 315 to $540 \mathrm{~m}$ (350 to $600 \mathrm{~ms}$ TWT) subsurface depths (Figure $1892 \mathrm{2}$ ). In some areas attenuation and scattering of the seismic signal suggest the presence of free gas 190 accumulation.

\section{4.3. Estimated geothermal gradient from BSR depth}

192 Variations in the thermal regime of sedimentary basins can be a good indicator of tectonic features 193 and/or fluid migration through the sedimentary column. In the undrilled part of the Tumbes Basin, the 194 geothermal gradient is computed using the inferred temperature at the BSR (Yamano et al., 1982; 
Multiple BSRs and fluid flow offshore Tumbes Basin, Peru. R1

195 Hyndman et al., 1992), assuming hydrostatic pressure, and a gas composition of pure methane, which 196 seems a good approximation for the Peru margin (Pecher et al., 2001). As temperature is available only at 197 the seabed (World Ocean Database, 2009), the estimated thermal gradient values are used only for 198 qualitative assessments. Using the methodology described above, the seafloor (water depth ranging from 199110 to $2765 \mathrm{~m}$ ), and the BSR (depth below seafloor ranging from 171 to $558 \mathrm{~m}$ ) are mapped in detail from 200 the 2D and 3D seismic dataset (Figures 7A and 7B). Temperature at the BSR is estimated from pressure201 temperature curves for seawater-methane hydrate stability based on experimental data, and the derived 202 geothermal gradient is mapped and extrapolated across the mapped BSR (Figure 7C). The average value 203 obtained, $26^{\circ} \mathrm{C} / \mathrm{km}$, is consistent with the regional thermal regime trend. In the Yaquina and Lima Basins,

204 Kvenvolden and Kastner (1990) obtained values of $40-50^{\circ} \mathrm{C} / \mathrm{km}$ at water depths greater than $3000 \mathrm{~m}$, 205 which fit with our estimation of a thermal gradient close to $40^{\circ} \mathrm{C} / \mathrm{km}$ at a water depth of $\sim 3000 \mathrm{~m}$.

206 In order to assess potential uncertainties due to gas composition, we use the seawater approximation 207 with variable mixtures of methane, ethane, and propane, i.e. $100 \%$ methane, mixte $(96 \%$ methane, $3 \%$ 208 ethane, $1 \%$ propane), and thermogenic ( $90 \%$ methane, $7 \%$ ethane, $3 \%$ propane). We then use an 209 average geothermal gradient of $25-40^{\circ} \mathrm{C} / \mathrm{km}$ for the study area (Figure 8 ), to estimate the approximate 210 expected depth of the hydrate stability zone, and therefore the potential depth of the BSR below the 211 seafloor. Hydrates are predicted to be stable in sediment from 125 to $780 \mathrm{~m}$ below seafloor, based on a 212 hydrate stability field for a three variable mixture of gas and assuming a $25-40^{\circ} \mathrm{C} / \mathrm{km}$ geothermal gradient 213 and water depths of 765, 950, 1115 and $1330 \mathrm{~m}$. Our results are summarized in Table 1.

\section{5. Discussion}

\section{5.1. Nature of the BSRs}

216 Although direct analyses of hydrate composition are not available in the Tumbes and Mancora Basins, 217 we interpret the upper BSR as the active BSR, in part because it is the BSR that shows the greatest 218 continuity and that is not affected by faults. Moreover, the data presented reveal that the upper BSR 219 corresponds to the present-day position of the base of the hydrate stability field, estimated from pressure220 temperature conditions exerted at seafloor and in sediment, and a gas composition comprised between $22196 \%$ methane and $4 \%$ of ethane, propane and pure methane. Locally, $\mathrm{CO}_{2}$ may be present as well as 222 thermogenic gases, according to the seawater-hydrate stability curves. These results seem consistent 
Multiple BSRs and fluid flow offshore Tumbes Basin, Peru. R1

223 with previous reported analyses done in the Piedra Redonda and Corvina gas wells, located eastward of 224 block Z-38 in the shallow depth Tumbes Basin, which show a gas composition with near 98\% methane 225 and $2 \%$ of ethane, propane and $\mathrm{CO}_{2}$ (Basin Evaluations Group Exploration Department, 2005).

226 For the other deeper BSR-type reflectors, which we interpret as possible hydrate-related BSRs, we have 227 three hypotheses:

228 (1) Intermediate and lower BSRs could represent the base of hydrates formed from a mixture of gases. 229 Hydrates with mixed compositions of methane and heavier natural gas components such as ethane, 230 propane or carbon dioxide, will cause an increase in depth of the base of the GHSZ, due to the 231 displacement of the phase boundary to higher temperature-pressure values (Sloan, 1998). In the Tumbes 232 Basin, we calculated that intermediate and lower BSRs are all within the stability range of hydrates for 233 variable mixtures of methane, ethane and propane (with less than $10 \%$ of the heavier hydrocarbon gases) 234 (Table 1). Conversely, in the intra-slope Mancora Basin, although both fluid-flow features and gas hydrate 235 accumulations may indicate the presence of a deep thermogenic gas source (Heggland, 1998), the HAA 236 occur at depths where the ambient temperature is too high for the hydrate to be stable, even in the 237 presence of more complex gas/fluid components (section SW-NE - Figure 3C). Our results may support 238 the hypothesis that intermediate and lower BSRs mark the base of hydrates of different gas compositions, 239 although no current data allows us to confirm this hypothesis.

240 (2) In response to variations in pressure and temperature conditions exerted on the GHSZ, vertical 241 displacement of the BSR is expected. Intermediate and lower BSRs could be interpreted as a remnant of 242 an older BSR that is in the process of dispersing, after a pressure drop and/or a temperature increase 243 (e.g. von Huene and Pecher, 1999; Foucher et al., 2002, Bangs et al., 2005). This hypothesis supposes 244 that the amount of free gas is still high enough that the reflectivity of the old BSR persists. Foucher et al. 245 (2002) estimated the duration of persistence of a diffusing gas layer at several thousand years, with a 246 maximum of the order of $10000 \mathrm{yr}$. We suggest three thermodynamic stability periods to form the lower, 247 intermediate, and upper BSRs, during the last $10000 \mathrm{yr}$ as required by the estimated short duration of the 248 BSR's reflectivity.

249 (3) We suggest that multiple BSRs may represent a permeability barrier (e.g. diagenetically induced) 250 formed when the active BSR existed stably at that level for an extended period. The permeability barrier 
Multiple BSRs and fluid flow offshore Tumbes Basin, Peru. R1

251 would allow the trapping and accumulation of free gas, which would be expressed in seismic data as a 252 negative reflection, and as a level at which enhanced reflections would terminate. We excluded here the 253 possibility of a diagenesis-related BSR resulting from the phase transitions between opal-A, opal-CT/-C,

254 and microcrystalline quartz, which displays the same polarity as the seafloor reflection, opposite to that of 255 a hydrate-related BSR (Berndt et al., 2004).

\section{5.2. Mechanisms at the origin of BSR migration}

257 Multiple BSRs that would correspond to a previously deeper phase boundary BSR, either in the process 258 of dispersing or diagenetically induced, have to readjust their position to current pressure and temperature 259 conditions. We will discuss the main mechanisms that could generate vertical movement of the base of 260 the GHSZ to explain their origin. In the Tumbes basin, these mechanisms are associated with eustatic, 261 tectonics and sedimentary processes, the main parameters that control the evolution of the basin through 262 time. We will not further develop the hypothesis of hydrates formed from a gas mixture, which would need 263 borehole data to be substantiated.

264 Since the last glacial maximum, the eustatic sea level increased by $125+/-5 \mathrm{~m}$ from $\sim 15$ to 7 ka and 265 stayed roughly constant from 7 ka until present time (Fleming et al., 1998), and bottom water temperature 266 was estimated $1.5^{\circ} \mathrm{C}$ cooler than today (data from deep-sea core $\mathrm{V}$ 19-30; $3091 \mathrm{~m}$ water depth, 267 Koutavas, et al., 2006) in the Equatorial Pacific Ocean (Chappell and Shackleton, 1986; Waelbroeck et al., 268 2002). Pressure and temperature changes affect the BSR with different timing. The pressure, which 269 increased nearly uniformly during $10 \mathrm{ka}$, is transferred immediately to the depth of the BSR. Conversely, 270 the thermal pulse associated with rising bottom-water temperatures propagates gradually, from the 271 seafloor down to the BSR depth, following the laws of thermal conduction (e.g. on the upper slope of the 272 eastern Nankai margin, Foucher et al. (2002) estimated a time delay of $4700 \mathrm{yr}$ before the thermal pulse 273 would affect local temperature conditions at $200 \mathrm{~m}$ sub-bottom depth, for a thermal diffusivity of the 274 sediments of $\left.3 \times 10-7 \mathrm{~m}^{2} / \mathrm{s},\right)$. In order to determine the possible depth of the paleo-BSR that could 275 correspond to the last glacial pressure-temperature conditions, we computed the depth of the BSR for a 276 seafloor temperature $1.5^{\circ} \mathrm{C}$ lower than today, assuming sea-level lowstand of $\sim 120 \mathrm{~m}$ for pure methane 277 hydrates and a geothermal gradient of $\sim 30^{\circ} \mathrm{C} / \mathrm{km}$ (Figure 9). Our results show that multiple BSRs can be 278 locally interpreted as the result of different stable climatic episodes, with temperature between glacial 
Multiple BSRs and fluid flow offshore Tumbes Basin, Peru. R1

279 values and the present-day conditions (for a mixte or thermogenic gas composition, the interval between 280 the two theoretical BRSs increases and includes the lower BSRs, see Table 1).. Nevertheless, the 281 importance of faulting and associated shift of the multiple BSRs lead us to suspect that tectonic 282 subsidence/uplift could play a major role in addition to sea level rise and thermal pulse.

283 In the Tumbes Basin, and more widely along the Peru margin, the presence or absence of a BSR is 284 largely controlled by tectonism and sedimentation (e.g. von Huene and Pecher, 1999). The Tumbes Basin 285 is defined as a complex forearc basin. It is controlled by detachment tectonics, the Tumbes and Zorritos 286 detachments, which accommodate the main subsidence phase that has been occuring since the late 287 Pliocene-Pleistocene until present time (Witt and Bourgois, 2010). We hypothesize that tectonic 288 subsidence is the main controlling factor for multiple BSRs generation. The intra-slope Mancora Basin 289 shows a nice example of such activity. Indeed, we suggest that the HAA shifted down observed in this 290 sub-basin are related to a paleo BSR, probably the same as that called 'lower BSR' observed in profile 3C. 291 The intra-slope Mancora Basin is located at the complex triple junction between the Tumbes detachment, 292 the normal fault bounding the eastern flank of Banco Peru, and the Talara detachment. It is controlled by a 293 major seaward-dipping listric fault (i.e., the Talara detachment, Witt and Bourgois, 2010), which controls 294 the subsidence of the intra-slope basin, and displaced the seafloor producing a $220 \mathrm{~m}$-high scarp. The 295 listric fault and the growth of antithetic faults are at the origin of the shift of the paleo-BSR (Figures 10A 296 and 10B). Thereafter, sediment deposition thickens towards the listric fault, increasing pressure and 297 temperature, causing the dissociation of the deepest segments of the BSR. This step probably coincides 298 with the first chimneys' appearance in the intra-slope basin and the reactivation of antithetic faults which 299 facilitated fluid migration (Figure 10C). The last sediment depositions are flat lying and are not cut by the 300 antithetic faults, which suggests a reduced activity of the listric fault, and a period of relatively stable P-T 301 conditions allowing the formation of the upper BSR (Figure 10D). The preservation of the reflectivity of the 302 old BSR supposes that amount of free gas remains stable enough to prevent it from dispersing quickly by 303 diffusion (Bangs et al., 2005). Little or no fluid advection is required to explain the retention of the lower 304 BSRs. The areas where intermediate BSRs occur have in common a structural architecture characterized 305 by high concentration of normal faults. We suggest that the fracture pathways may contribute to disperse 306 BSRs faster due to upward migration of warm fluid migration which partially destroys the multiple BSRs 
Multiple BSRs and fluid flow offshore Tumbes Basin, Peru. R1

307 (Tréhu et al., 2006). Moreover, lower BSRs in these zones are usually very faint or absent, which is 308 consistent with this hypothesis.

309 5.3. Plumbing system and BSR

310 The plumbing system of the Tumbes-Mancora Basin for its shallow portion is complex with faults 311 outcropping at the seafloor surface and buried to outcropping gas chimneys/pipes and pockmarks

312 (Figures 1B, 2, 5 and 6). The inferred evidence from the BSRs for hydrate bearing sediments means that 313 the fluids that circulate/migrates within these basins can be trapped due to high pressure and low 314 temperature at seafloor. The buried features such as gas chimneys show vertical migration rather that 315 stratal migration from deeper sourced fluids to the shallow subsurface. This is well depicted by the faults 316 mapped within the 3D area covered of the Mancora Basin (Figures 5 and 6 ). Figures 5 and 6 illustrate the 317 location of vertical discontinuities such as gas chimneys that originates from various depth levels. They 318 are not all spatially linked to the presence of the BSR. They illustrate various levels of source/root zones 319 such as compiled by Cartwright and Santamarina (2015), with the source being above, at and below the 320 BSR in various hydrates provinces. The relation between pipes/gas chimneys and hydrate is not yet fully 321 understood (e.g. Paull et al., 2008). The highly heterogeneous occurrence of the root zones of pipes/gas 322 chimneys around the GHSZ and BSR might express the complex variations of mechanism related to 323 fracture induced processes due to upward migration of free gas and hydrate nucleation and/or dissociation 324 related to physical/chemical processes.

\section{6. Conclusions}

326 Seismic data acquired in the Tumbes Basin have revealed the occurrence of an extended active 327 hydrate-related BSR, and multiple BSRs observed at different sub-bottom depths below, comprising a 328 lower BSR of high reflectivity and several soft intermediate BSRs localized within the interval between the 329 active and lower BSR. We have focused our attention on the multiple BSRs which may represent 330 segments of residual BSRs in the process of dispersing, or related to a permeability barrier left behind 331 after an upward displacement of the base of the GHSZ. They have been interpreted as three events of 332 steady state in the pressure and temperature conditions, produced by climatic episodes since the last 333 glaciation associated with tectonic activities, essentially tectonic subsidence regarding the Tumbes334 Mancora Basins. This paper document hydrates using seismic data only. Further investigations must be 
Multiple BSRs and fluid flow offshore Tumbes Basin, Peru. R1

335 conducted by developing geophysical tools, and drilling cores in hydrate zones, to better understand the

336 distribution of gas hydrates in sediment and the nature of the multiple BSRs in the area.

\section{Acknowledgements}

338 We thank PeruPetro for providing access to the seismic data, IHS-KINGDOM and dGB-OpendTect for

339 academic software donation. An earlier version of this manuscript has been critically and constructively

340 reviewed by T. Alves, M. De Batist, M. Huuse and C. Série. We are grateful to the anonymous referee,

341 Philippe Schnürle and the editor Wu-Cheng Chi, who provided constructive suggestions.

\section{Conflict of Interest}

343 The authors declare that they have no conflict of interest.

\section{References}

345 Andreassen K., Mienert J., Bryn P., Singh S.C. (2000) A double gas-hydrate related bottom-simulating 346 reflector at the Norwegian continental margin. Ann. N.Y. Acad. Sci., 912, 126-135. doi:10.1111/j.1749$347 \quad 6632.2000 . t b 06766 . x$

348 Ashi J., Tokuyama H., Taira A. (2002) Distribution of methane hydrate BSRs and its implication for the 349 prism growth in the Nankai Trough. Marine Geology, 187, 177-191. doi:10.1016/S0025-3227(02)00265$350 \quad 7$

351 Ballard A. L., Sloan E. D. (2002) The next generation of hydrate prediction: I. Hydrate standard states and 352 incorporation of spectroscopy. Fluid Phase Equilibria, 194, 371-383. doi:10.1016/S0378$353 \quad 3812(01) 00697-5$

354 Bangs N. L. B., Musgrave R. J., Tréhu A. M. (2005) Upward shifts in the southern Hydrate Ridge gas 355 hydrate stability zone following postglacial warming, offshore Oregon. Journal of Geophysical Research, 356 110, B03102. doi:10.1029/2004JB003293

357 Berndt C., Bünz S., Clayton T., Mienert J., Saunders M. (2004) Seismic character of bottom-simulating 358 reflections: examples from the mid-Norwegian margin. Mar. Pet. Geol., 21, 723-733. 359 doi:10.1016/j.marpetgeo.2004.02.003

360 Bourgois J., Bigot-Cormier F., Bourles D., Braucher R., Dauteuil O., Witt C., Michaud F. (2007) Tectonic 361 record of strain buildup and abrupt coseismic stress release across the northwestern Peru coastal plain, 
Multiple BSRs and fluid flow offshore Tumbes Basin, Peru. R1

shelf, and continental slope during the past 200 kyr. Journal of Geophysical Research: Solid Earth, 112, B04104, doi: 10.1029/2006JB004491.

364 Brown K. M., Bangs N. L., Froelich P. N., Kvenvolden K. A. (1996) The nature, distribution, and origin of gas hydrate in the Chile Triple Junction region. Earth and Planetary Science Letters 139, 471-483. doi: $10.1016 / 0012-821 \times(95) 00243-6$

Calvès G., M. Huuse, A. Schwab, and P. Clift (2008) Three-dimensional seismic analysis of highamplitude anomalies in the shallow subsurface of the Northern Indus Fan: Sedimentary and/or fluid origin, J. Geophys. Res., 113, B11103, doi: 10.1029/2008JB005666.

370 Calvès G., Schwab A. M., Huuse M., Clift P. D., Inam A. (2010) Thermal regime of the northwest Indian

371 rifted margin - Comparison with predictions. Marine and Petroleum Geology, 27, 1133-1147. doi:

$372 \quad 10.1016 / j \cdot m a r p e t g e o .2010 .02 .010$

373 Cartwright J., Santamarina C. (2015), Seismic characteristics of fluid escape pipes in sedimentary basins:

374 Implications for pipe genesis. Marine and Petroleum Geology, 65, 126-140, doi: 375 10.1016/j.marpetgeo.2015.03.023.

376 Chappell J., Shackleton N. J. (1986) Oxygen isotopes and sea level. Nature, 324, 137-140. 377 doi:10.1038/324137a0

378 Deckelman J., Connors F., Shultz A., Glagola P., Menard W., Schwegal S.- ConocoPhillips Company; 379 Shearer, J.- Applied Petrologic Technology. (2005) An Integrated Characterization of Neogene Oil and 380 Gas Reservoirs, Progreso Basin, Offshore Ecuador \& Peru: Implications for Petroleum Exploration and 381 Exploitation. Perupetro S.A. INGEPET 2005.

382 Field M. E., Kvenvolden K. A. (1985) Gas hydrates on the northern California continental margin. Geology, 383 13, 517-520. doi:10.1130/0091-7613(1985)13<517:GHOTNC>2.0.CO;2

384 Fleming K., Johnston P., Zwartz D., Yokoyama Y., Lambeck K., Chappell J. (1998) Refining the eustatic 385 sea-level curve since the Last Glacial Maximum using far- and intermediate-field sites. Earth and 386 Planetary Science Letters 163, 327-342. doi: 10.1016/S0012-821X(98)00198-8

387 Foucher J.-P., Nouzé H., Henry P. (2002) Observation and tentative interpretation of a double BSR on the 388 Nankai slope. Marine Geology, 187, 161-175. doi: 10.1016/S0025-3227(02)00264-5 
Multiple BSRs and fluid flow offshore Tumbes Basin, Peru. R1

389 Heggland R. (1998) Gas seepage as an indicator of deeper prospective reservoirs. A study based on 390 exploration 3D seismic data. Marine and Petroleum Geology 15, 1-9. doi:10.1016/S0264391 8172(97)00060-3

392 Herbozo G., Hübscher C., Kaul N., Wagner M., Pecher I., Kukowski N. (2013) Influence of recent 393 depositional and tectonic controls on marine gas hydrates in Trujillo Basin, Peru Margin. Marine 394 Geology, 340, 30-48. doi: 10.1016/j.margeo.2013.04.010

395 Hübscher C., Kukowski N. (2003) Complex BSR pattern in the Yaquina Basin off Peru. Geo-Mar Lett, 23, 396 91-101. doi:10.1007/s00367-003-0128-z

397 Hustoft S., Bünz S., Mienert J., Chand S. (2009) Gas hydrate reservoir and active methane-venting 398 province in sediments on $<20$ Ma young oceanic crust in the Fram Strait, offshore NW-Svalbard. Earth 399 and Planetary Science Letters. doi:10.1016/j.epsl.2009.03.038.

400 Hyndman R. D., Davis E. E. (1992) A mechanism for the formation of methane hydrate and seafloor 401 bottom-simulating reflectors by vertical fluid expulsion. Journal of Geophysical Research: Solid Earth, 402 97(B5), 7025-7041. doi: 10.1029/91JB03061

403 Hyndman R. D., Foucher J. P., Yamano M., Fisher A., Scientific Team of Ocean Drilling Program Leg 131. 404 (1992) Deep sea bottom-simulating-reflectors: calibration of the base of the hydrate stability field as used 405 for heat flow estimates. Earth and Planetary Science Letters, 109, 289-301. doi: 10.1016/0012406 821X(92)90093-B

407 Judd A. G., Hovland M. (2009) Seabed fluid flow: the impact on geology, biology and the marine 408 environment. Cambridge University Press.

409 Koutavas, A., de Menocal P. B., Olive G. C., and Lynch-Stieglitz J. (2006), Mid-Holocene El Niño410 Southern Oscillation (ENSO) attenuation revealed by individual foraminifera in eastern tropical Pacific 411 sediments. Geology, 34(12), 993-996, doi:10.1130/g22810a.1

412 Kvenvolden K. A., Kastner M. (1990) Gas hydrates of the peruvian outer continental margin. Proceedings 413 of the Ocean Drilling Program, Scientific Results, 112.

414 Kvenvolden K. A. (1993) Gas hydrates-geological perspective and global change. Reviews of 415 Geophysics, 31, 173-187. doi: 10.1029/93RG00268 
Multiple BSRs and fluid flow offshore Tumbes Basin, Peru. R1

416 Lin C-.C., Lin A.T.-S., Liu C.-S., Chen G.-Y., Liao W.-Z., Schnurle P. (2008) Geological controls on BSR 417 occurrences in the incipient arc-continent collision zone off southwest Taiwan. Marine and Petroleum 418 Geology, 26, 1118-1131. doi: 10.1016/j.marpetgeo.2008.11.002

419 Milkov A. V. (2004) Global estimates of hydrate-bound gas in marine sediments: how much is really out 420 there? Earth-Science Reviews, 66, 183-197. doi: 10.1016/j.earscirev.2003.11.002

421 Mitchum R. M., Vail P. R., Sangree J. B. (1977) Stratigraphic interpretation of seismic reflection patterns in 422 depositional sequences, Part 6: in C. E. Payton, ed., Seismic Stratigraphy: Application to Hydrocarbon 423 Exploration, 8th ed., 117-133, Am. Assoc. of Pet. Geol., Tulsa, Okla.

424 Mosher D. C. (2008) Bottom Simulating Reflectors on Canada's East Coast Margin: Evidence for Gas 425 Hydrate. Proceedings of the 6th International Conference on Gas Hydrates, Vancouver, British 426 Columbia, CANADA, July 6-10.

427 Paull, C.K., Ussler lii W., Holbrook W.S., Hill T.M., Keaten R., Mienert J., Haflidason H., Johnson J.E., 428 Winters W.J., Lorenson T.D. (2008), Origin of pockmarks and chimney structures on the flanks of the 429 Storegga Slide, offshore Norway. Geo-Marine Letters, 28(1), 43-51, doi: 10.1007/s00367-007-0088-9

430 Pecher I. A., Kukowski N., Huebscher C., Greinert J., Bialas J., the GEOPECO Working Group. (2001) 431 The link between bottom-simulating reflections and methane flux into the gas hydrate stability zone 432 new evidence from Lima Basin, Peru Margin. Earth and Planetary Science Letters, 185, 343-354. 433 doi:10.1016/S0012-821X(00)00376-9

434 Popescu I., De Batist M., Lericolais G., Nouzé H., Poort J., Panin N., Versteeg W., Gillet H. (2006) Multiple 435 bottom-simulating reflections in the Black Sea: Potential proxies of past climate conditions. Marine 436 Geology, 227, 163-176. doi: 10.1016/j.margeo.2005.12.006

437 Posewang J., Mienert J. (1999) The enigma of double BSRs: Indicators for changes in the hydrate stability 438 field? Geo Mar. Lett., 19, 157-163. doi: 10.1007/s003670050103

439 Rodrigo C., Vera E., González-Fernández A. (2009) Seismic analysis and distribution of a bottom440 simulating reflector (BSR) in the Chilean margin offshore of Valdivia $\left(40^{\circ} \mathrm{S}\right)$. Journal of South American 441 Earth Sciences 27, 1-10. doi: 10.1016/j.jsames.2008.11.001 
Multiple BSRs and fluid flow offshore Tumbes Basin, Peru. R1

442 Shipley T. H., Houston M. H., Buffler R. T., Shaub F. J., McMillen K. J., Ladd J. W., Worzel J. L. (1979)

443 Seismic evidence for widespread possible gas hydrate horizons on continental slopes and rises. AAPG 444 bulletin, 63, 2204-2213.

445 Sloan E. D. (1998) Clathrate Hydrates of Natural Gases, second ed. Marcel Dekker Inc., New York \& 446 Basel, $705 \mathrm{pp}$.

447 Sultan N., Cochonat P., Foucher J. P., Mienert J. (2004) Effect of gas hydrates melting on seafloor slope 448 instability. Marine Geology, 213, 379-401. doi: 10.1016/j.margeo.2004.10.015

449 Tréhu A. M., Ruppel C., Holland M., Dickens G. R., Torres M. E., Collett T. S., Goldberg D., Riedel M., 450 Schultheiss P. (2006) Gas hydrates in marine sediments - Lessons from scientific ocean drilling. 451 Oceanography, 19, no. 4, 124-142.

452 Vanneste M., De Batist M., Golmshtok A., Kremlev A., Versteeg W. (2001) Multi- frequency seismic study 453 of gas hydrate-bearing sediments in Lake Baikal, Siberia. Marine Geology, 172, 1-21. Doi: $454 \quad 10.1016 / S 0025-3227(00) 00117-1$

455 Vanneste M., Poort J., De Batist M., Klerkx J. (2003) Atypical heat-flow near gas hydrate irregularities and 456 cold seeps in the Baikal Rift Zone. Marine and Petroleum Geology, 19, 1257-1274. doi: 10.1016/S0264457 8172(03)00019-9

458 von Huene R., Suess E., Emeis K. C. (1987) Convergent tectonics and coastal upwelling: a history of the 459 Peru continental margin. Episodes, 10, 87-93.

460 von Huene R., Pecher I. A. (1999) Vertical tectonics and the origins of BSRs along the Peru margin. Earth 461 and Planetary Science Letters, 166, no.1, 47-55. doi: 10.1016/S0012-821X(98)00274-X

462 Waelbroeck C., Labeyrie L., Michel E., Duplessy J. C., McManus J. F., Lambeck K., Balbon E., 463 Labracherie M. (2002) Sea-level and deep water temperature changes derived from benthic foraminifera 464 isotopic records. Quat. Sci. Rev., 21, 295-305. doi: 10.1016/S0277-3791(01)00101-9

465 Witt C., Bourgois J. (2010) Forearc basin formation in the tectonic wake of a collision-driven, coastwise 466 migrating crustal block: The example of the North Andean block and the extensional Gulf of Guayaquil467 Tumbes Basin (Ecuador-Peru border area). Geological Society of America Bulletin, 122, 89-108. doi: $468 \quad 10.1130 / B 26386.1$ 
Multiple BSRs and fluid flow offshore Tumbes Basin, Peru. R1

469 Yamano M., Uyeda S., Aoki Y., Shipley T. H. (1982). Estimates of heat flow derived from gas hydrates. 470 Geology, 10, 339-343. doi: 10.1130/0091-7613(1982)10<339:EOHFDF>2.0.CO;2

\section{Figure captions and tables}

472 Figure 1: (A) Location map of the main sedimentary basins along the Peruvian margin. The red box is the 473 study area covered by seismic reflection data. The red dots mark the scientific boreholes from ODP Leg 474 112. The black dot marks the location of core V19-30 (Koutavas, et al., 2006). (B) Bathymetric map of 475 the study area in the Tumbes Basin. Banco Peru, a flat shallow-depth bathymetric high, marks the NW 476 limit of the basin. The 3D seismic survey is represented by the black dashed line; the similarity attribute 477 at seafloor reflection is highlighting discontinuities such as faults. The location of seismic figures 478 illustrating bottom-simulating reflectors (BSRs) is represented by black straight lines. The red dashed 479 box shows the Mancora Basin sub area in the 3D seismic block (Figures 5 and 6). (C) SW-ENE transect 480 of the basin using $2 \mathrm{D}$ and $3 \mathrm{D}$ seismic profiles showing the main tectonic features. (D) 2D seismic profile 481 illustrating the BSR in the SW of the Mancora Basin.

482 Figure 2: (A) Uninterpreted and interpreted line showing examples of DHIs in the intra-slope Mancora 483 Basin. Seismic reflections of high amplitudes are present close to the depth of the BSR. Three horizons $484(\mathrm{H} 1, \mathrm{H} 2, \mathrm{H} 3)$ have been picked at different depths in order to intersect the BSR, and differentiate high 485 amplitude anomalies (HAA) due to sedimentary or structural elements from those due to the BSR. The 486 profile shows a singular HAA located beneath the BSR (yellow triangle) identified as a flat spot in NW487 SE oriented profiles. (B) Example of DHIs revealing the presence of a BSR indicated by black triangles, 488 dim out and phase reversal on a sedimentary layer of high amplitude intersected by a BSR, free gas 489 bearing sedimentary layer of high amplitude ending onto a BSR, and seismic chimney rooted at the BSR 490 depth. See Figure 1B for location.

491 Figure 3: Reflection seismic lines from the combined 2D and 3D seismic dataset showing evidence of 492 BSRs, and multiple BSRs (intermediate and lower BSRs). See Figure 1B for location.

493 Figure 4: (A) Time structure map below seafloor of the distribution of the BSR, and (B) multiple BSRs. 494 Seafloor time contours are labelled for reference. (C and D) Multiple BSRs stacking details, see Figure 495 $3 A$. 
Multiple BSRs and fluid flow offshore Tumbes Basin, Peru. R1

496 Figure 5: Similarity attribute map of the seafloor highlighting the location of chimneys at the seafloor (red), and buried chimneys (yellow). Seismic chimneys ending with mounds or pockmarks at the present day seafloor ( $\alpha$ and $\beta$ ), and buried chimneys ending with an intra-sedimentary doming $(\gamma)$ or a patch of HAA $(\delta)$

500 Figure 6: Blended TWT-structure and similarity maps of the seafloor $(A)$ and three horizons $(\mathrm{H} 1, \mathrm{H} 2, \mathrm{H} 3)$

501 (B, C, D) showing the relationship between faults azimuth and chimneys, the rose diagrams indicating the normal fault trend. The deepest horizon evidenced the highest fault density of the Mancora Basin.

503 Figure 7: Results from a detailed analysis of the base of the gas hydrate stability zone (GHSZ) within the 2D seismic dataset. (A) Water depth map assuming $1500 \mathrm{~m} / \mathrm{s}$ seawater velocity; (B) Gas hydrate stability zone thickness assuming $1800 \mathrm{~m} / \mathrm{s}$ sediment velocity;

(C) Geothermal gradient computed across the mapped BSR. Contours interval is $200 \mathrm{~m}$.

507 Figure 8: Stability conditions for gas hydrate from depth-temperature readings within the study area.

508 Seawater temperature data compiled from World Ocean Database 2009. The theoretical curves are 509 calculated for seawater-methane approximation with different gas compositions using the program 510 CSMHYD of Sloan (1998).

511 Figure 9: Plots of observed upper BSR (black line), intermediate BSR (blue line), and lower BSR (yellow 512 line), and computed positions of the upper BSR for present and glacial temperature and pressure 513 conditions. See Figure 3 for original seismic observation of the BSRs.

514 Figure 10: Diagram showing how tectonic subsidence and sedimentation influence the depth and shape of 515 the BSR in Figure 2A. (A) Initial state; (B) Listric normal fault developement and downward shift of the 516 BSR; (C) Sedimentation and fault reactivation. Dissociation of hydrates (BSR) near the contact with the 517 foot wall; (D) Sedimentation without faults reactivation. Free gas accumulation near the listric fault plane.

518 Table 1: Scenario of base of hydrate stability zone below seafloor for given water depths, different gas 519 composition, and geothermal gradient. Observed BSRs depth is from the Tumbes Basin.

\begin{tabular}{|c|c|c|c|c|c|c|c|c|c|c|c|c|c|}
\hline \multicolumn{2}{|l|}{ Water depth (m) } & \multicolumn{3}{|c|}{765} & \multicolumn{3}{|c|}{950} & \multicolumn{3}{|c|}{1115} & \multicolumn{3}{|c|}{1330} \\
\hline \multicolumn{2}{|c|}{ Seafloor temperature $\left({ }^{\circ} \mathrm{C}\right)$} & \multicolumn{3}{|c|}{5.8} & \multicolumn{3}{|c|}{4.8} & \multicolumn{3}{|c|}{4.2} & \multicolumn{3}{|c|}{3.4} \\
\hline \multicolumn{2}{|c|}{ Gas composition } & $100 \% \mathrm{CH} 4$ & $96 \% \mathrm{CH} 4$ & $90 \% \mathrm{CH} 4$ & $100 \% \mathrm{CH} 4$ & $96 \% \mathrm{CH} 4$ & $90 \% \mathrm{CH} 4$ & $100 \% \mathrm{CH} 4$ & $96 \% \mathrm{CH} 4$ & $90 \% \mathrm{CH} 4$ & $100 \% \mathrm{CH} 4$ & $96 \% \mathrm{CH} 4$ & $90 \% \mathrm{CH} 4$ \\
\hline Predicted GHSZ & geotherm $25^{\circ} \mathrm{C} / \mathrm{km}$ & 245 & 425 & 615 & 390 & 530 & 680 & 475 & 585 & 725 & 550 & 645 & 780 \\
\hline thickness (m) & geotherm $40^{\circ} \mathrm{C} / \mathrm{km}$ & 125 & 235 & 245 & 215 & 300 & 410 & 250 & 325 & 420 & 300 & 360 & 445 \\
\hline $\begin{array}{l}\text { Observed BSR } \\
\text { depth (mbsf) }\end{array}$ & $\begin{array}{l}\text { upper BSR } \\
\text { lower BSR } \\
\end{array}$ & \multicolumn{3}{|c|}{$\begin{array}{l}225 \\
351\end{array}$} & \multicolumn{3}{|c|}{$\begin{array}{l}306 \\
414\end{array}$} & \multicolumn{3}{|c|}{$\begin{array}{l}432 \\
567\end{array}$} & & 441 & \\
\hline
\end{tabular}



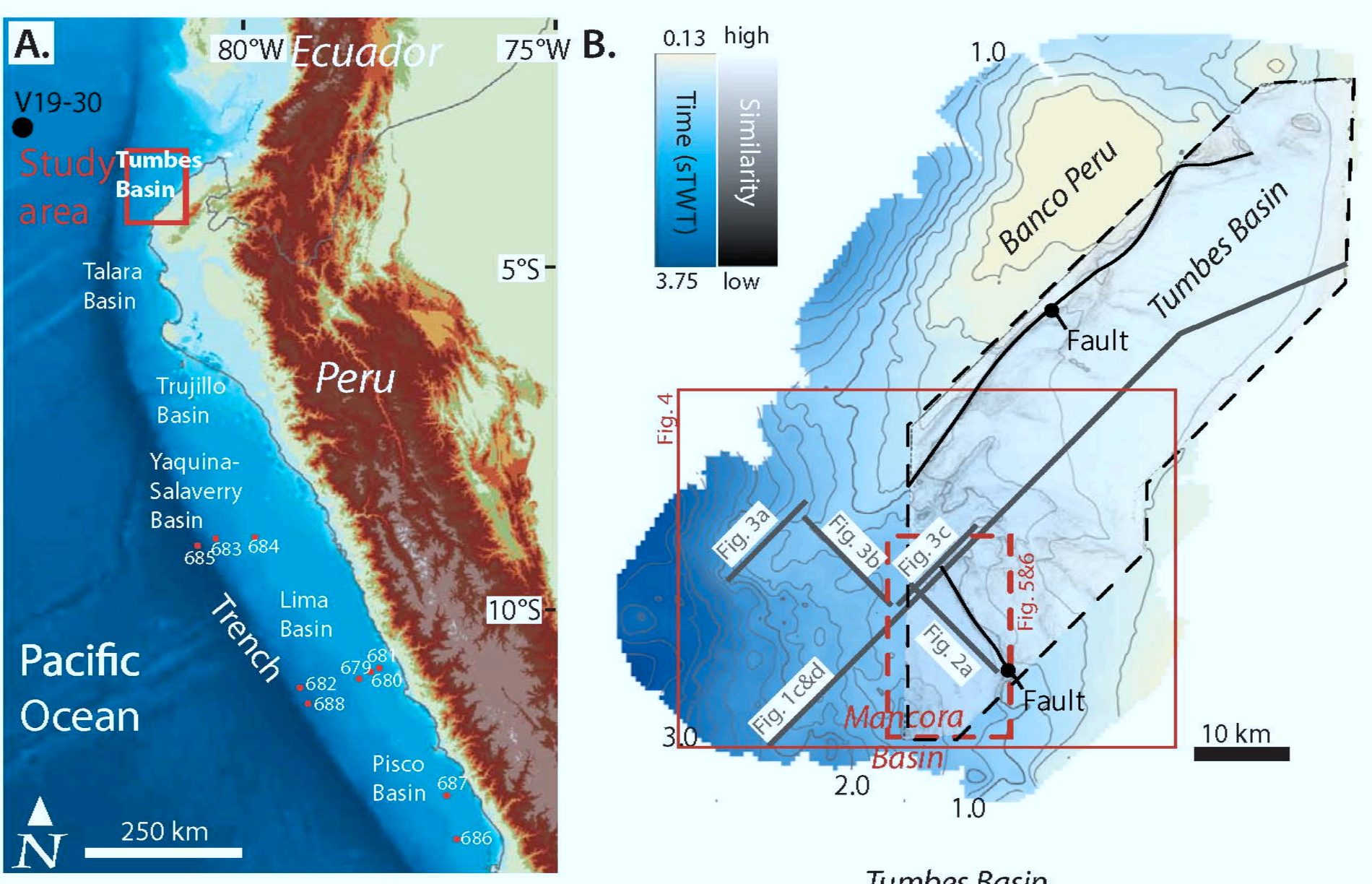

C. Mancora Basin

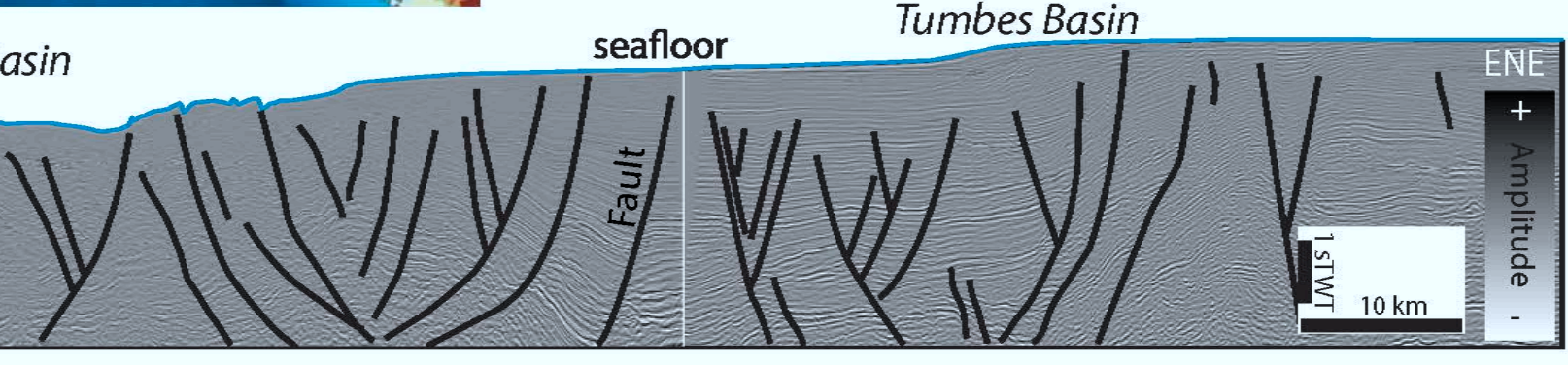

D
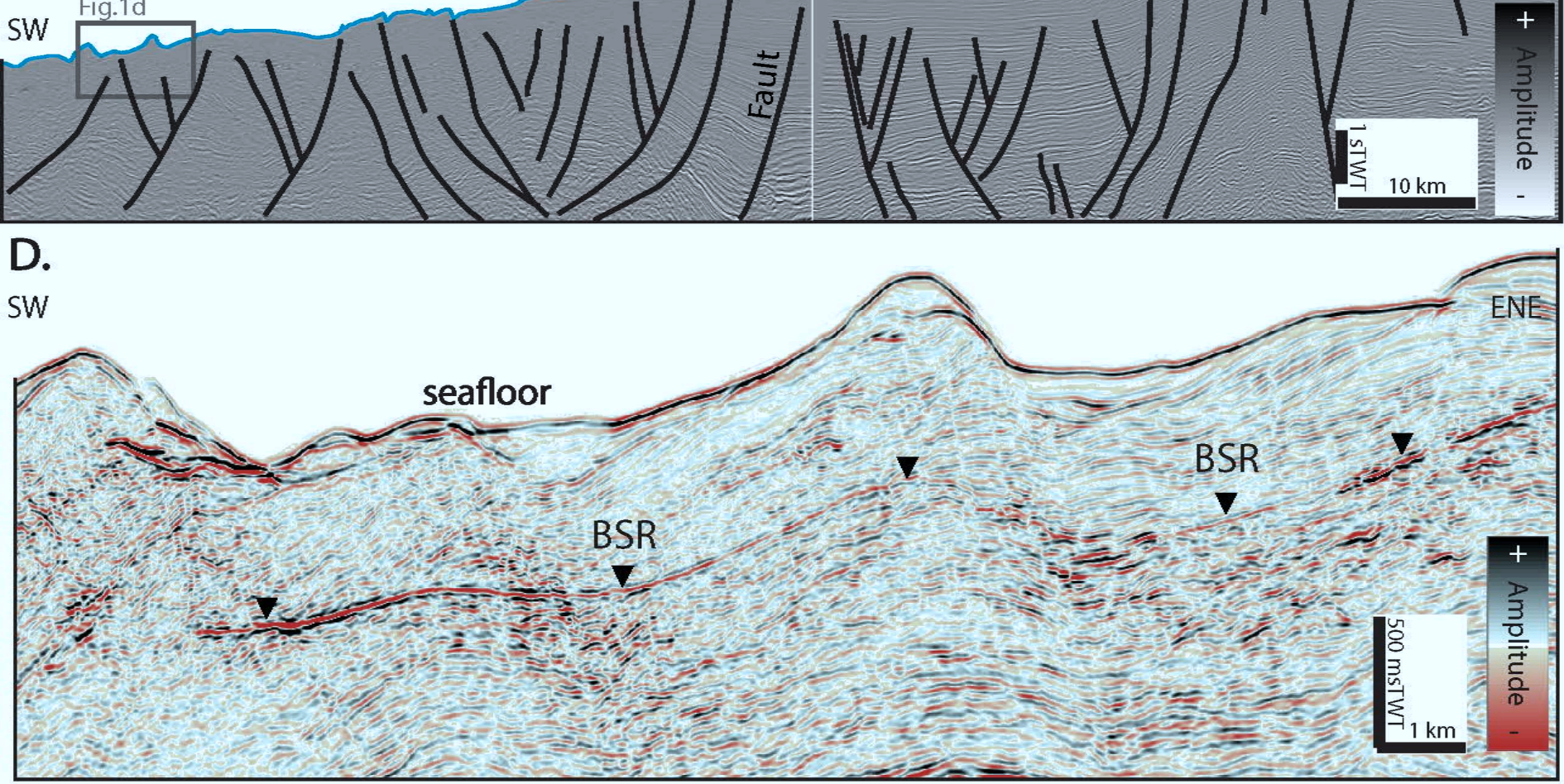

Figure 1 

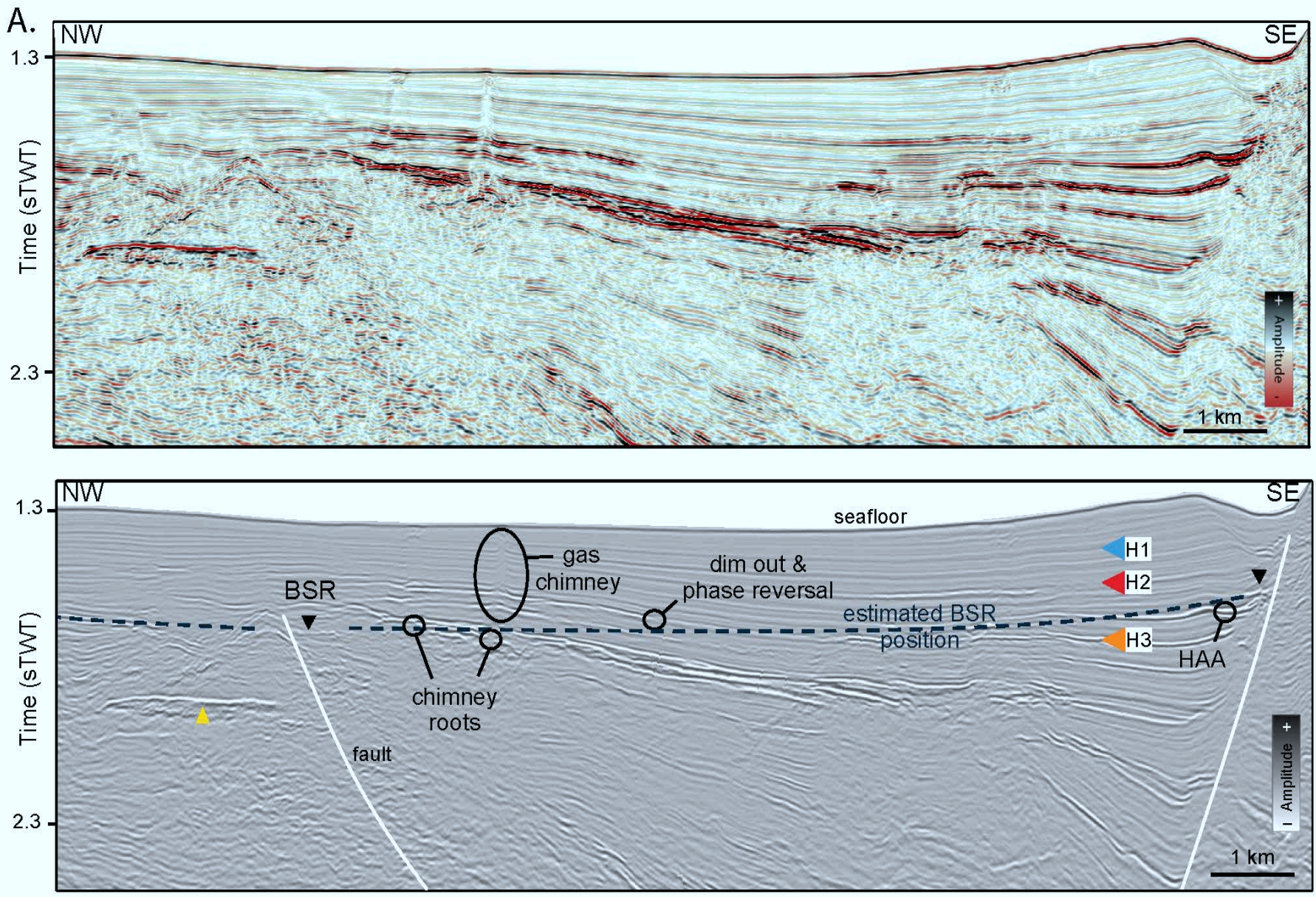

B.
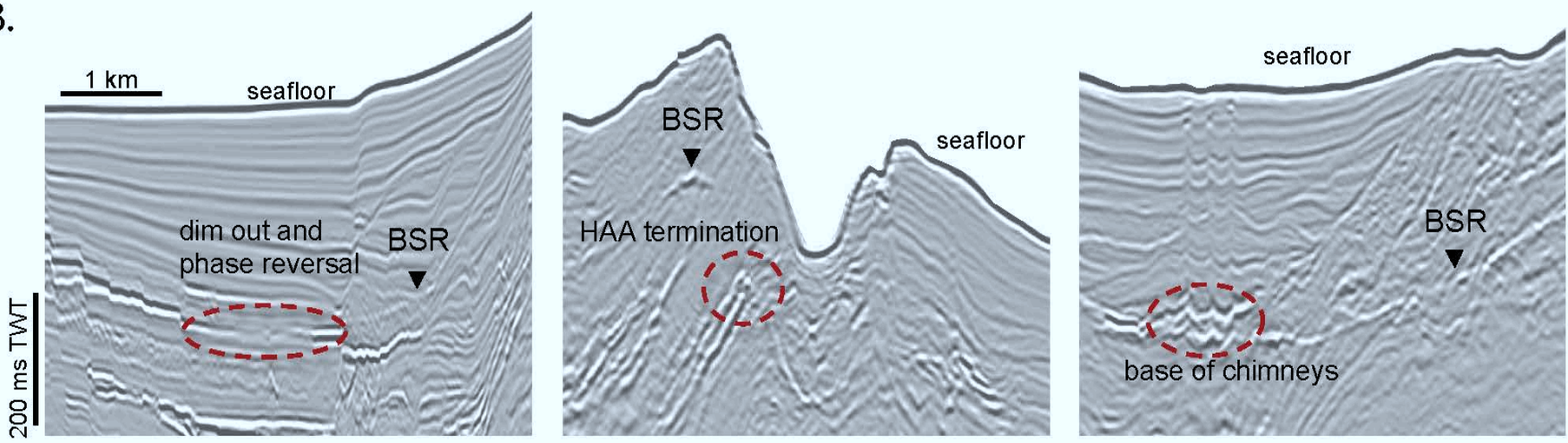

Figure 2 

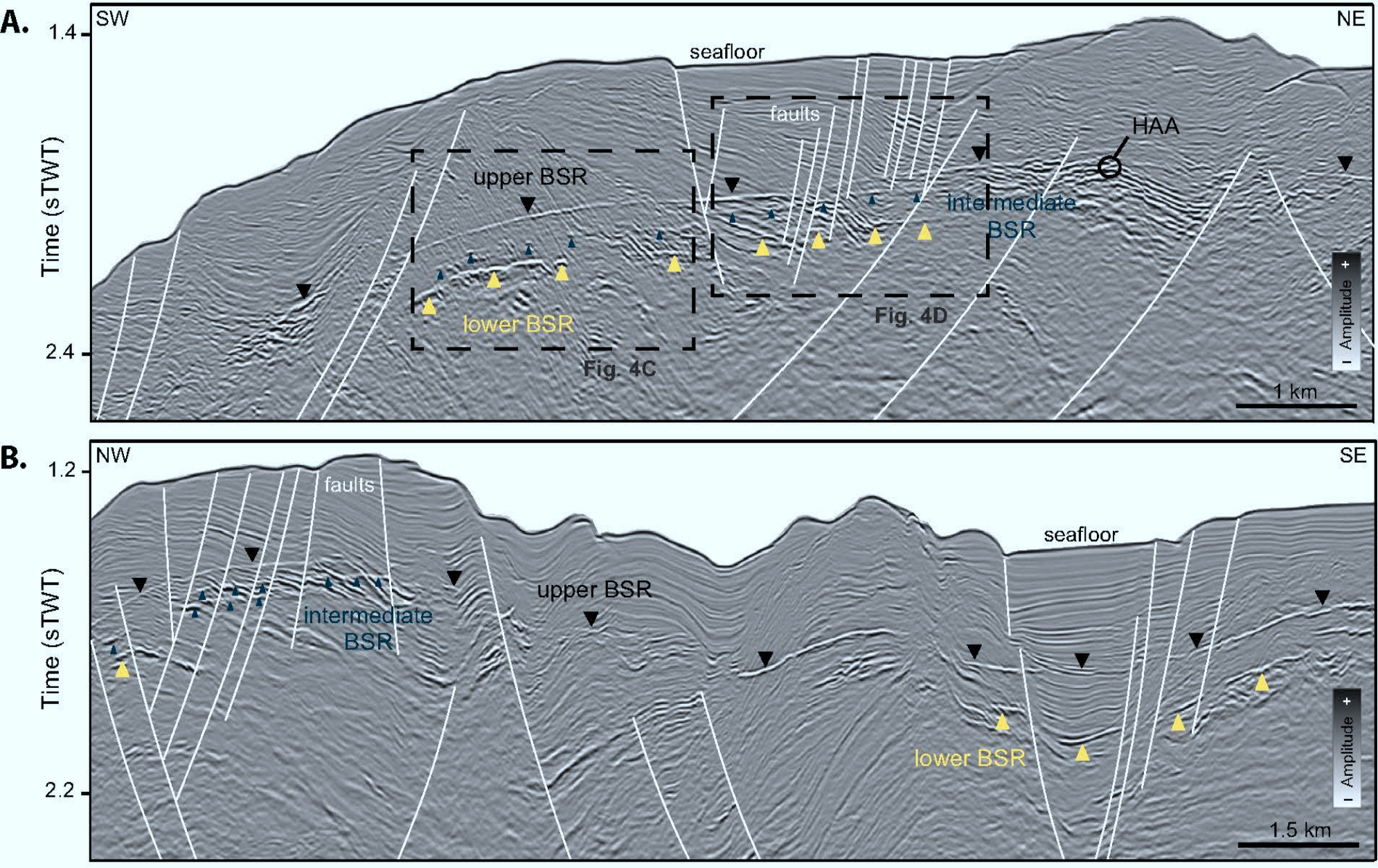

c.

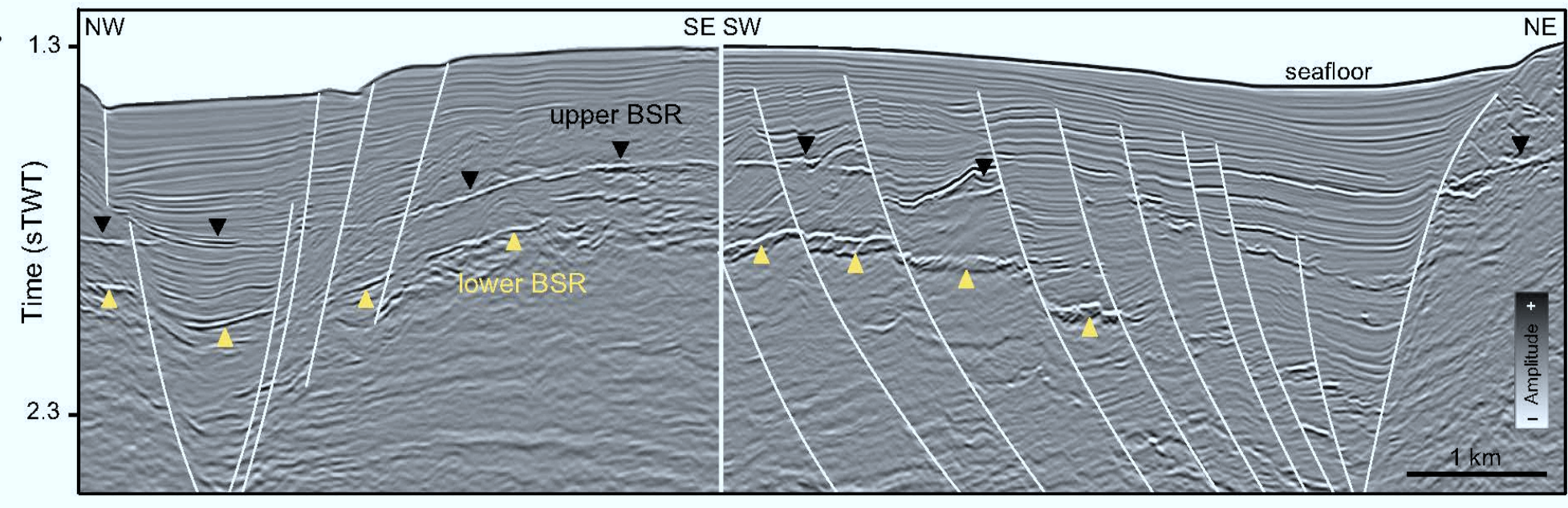

Figure 3 


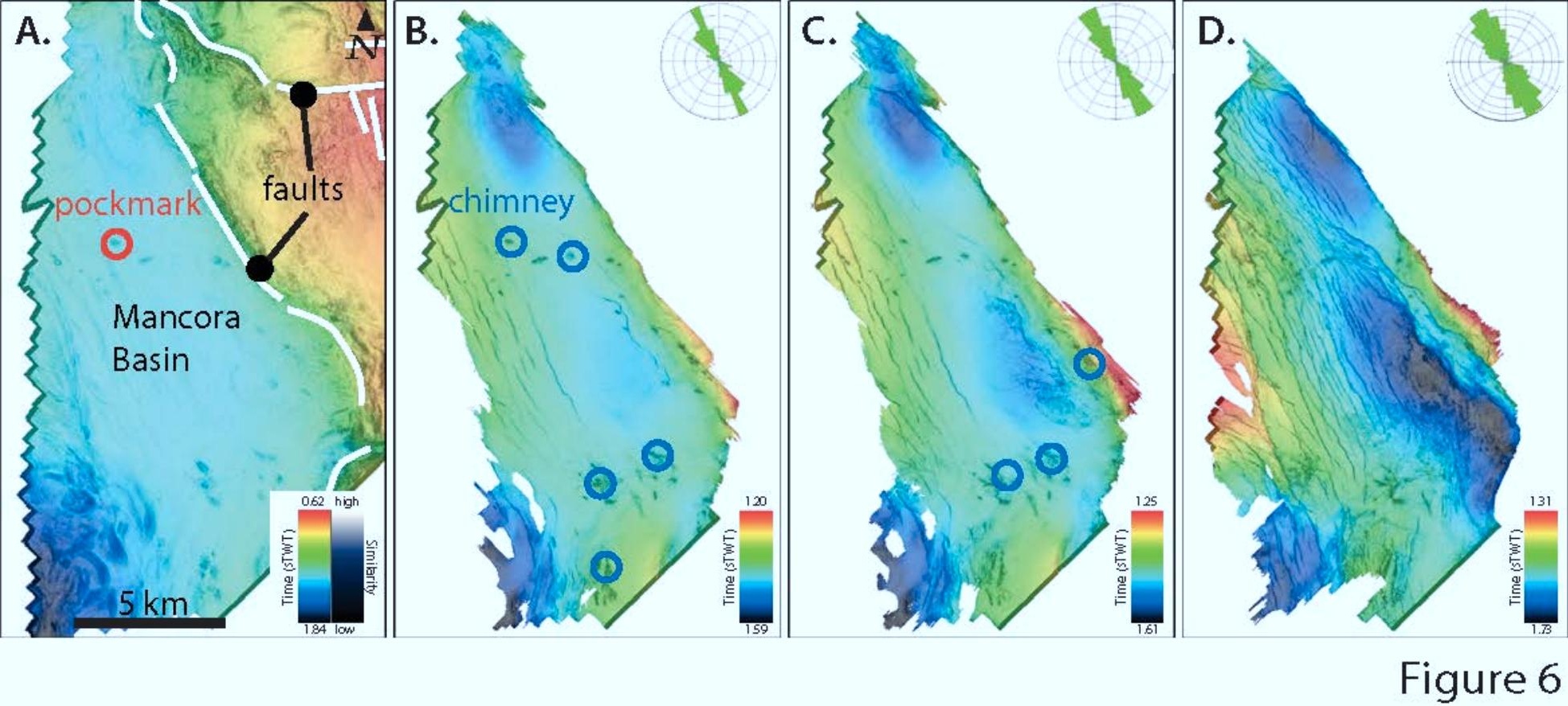




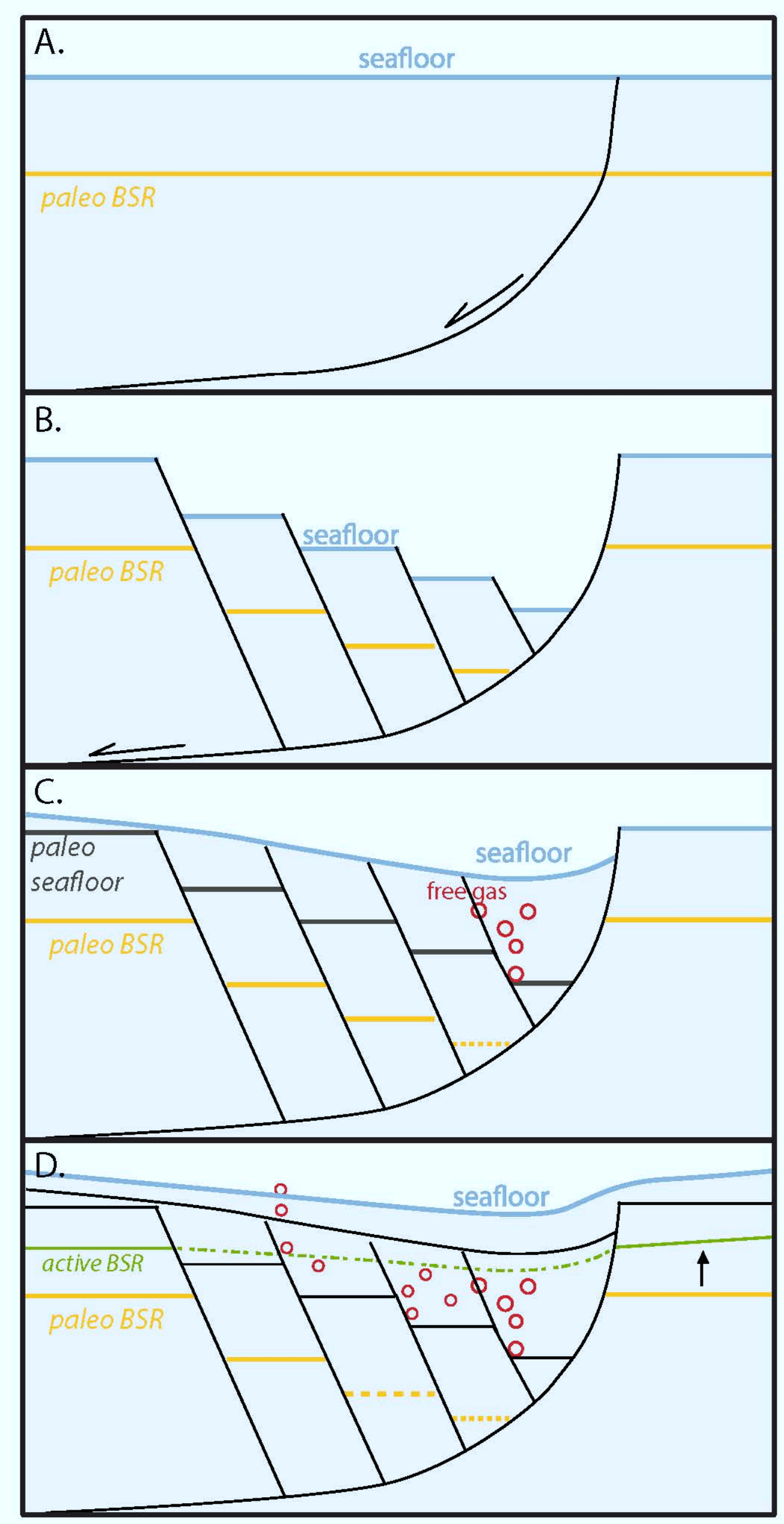

Figure 10 